\title{
Tax Co-ordination in Europe: Assessing the First Years of the EU-Savings Taxation Directive
}

\author{
THOMAS HEMMELGARN \\ GAËTAN NICODÈME
}

CESIFo WORKING PAPER NO. 2675

CATEGORY 1: Public FinANCE

JUNE 2009
An electronic version of the paper may be downloaded
- from the SSRN website: www.SSRN.com
- from the RePEc website: $\quad$ www.RePEc.org
- from the CESifo website: www.CESifo-group.org/wp




\title{
Tax Co-ordination in Europe: Assessing the First Years of the EU-Savings Taxation Directive
}

\begin{abstract}
This paper reviews the economic effects of the EU Savings Taxation Directive. The Directive aims at enabling taxation of foreign interest payments received by individuals in accordance with the rules of their State of residence. The data suggest that the Directive, which is based on automatic information exchange, has not led to major shifts in international savings. However, this result has to be interpreted with caution since the available data is scarce and not always conclusive.
\end{abstract}

JEL Code: F21, F33, G12, G28, H24, H26, H87, K34, O16.

Keywords: savings taxation, withholding tax, information exchange, European Union.

Thomas Hemmelgarn

European Commission

thomas.hemmelgarn@ec.europa.eu
Gaëtan Nicodème

European Commission

gaetan.nicodeme@ec.europa.eu

This version: June 2009

The views expressed in this article are those of the authors and do not necessarily reflect the official position of the European Commission. The authors thank Germano Mirabile, Michèle Perolat and Jean-Pierre De Laet for valuable comments. (C) European Communities, 2009. 


\section{Introduction}

The analysis of tax competition and tax co-ordination has a long tradition in public economics. $^{2}$ A considerable part of the literature comes to the conclusion that in a world with tax competition, tax rates on the income of mobile factors might be inefficiently low and tax co-ordination would be welfare enhancing. ${ }^{3}$ However, in reality there are only very few examples where governments actually agree to co-ordinate tax policies internationally. One example of a co-ordination on the international level is the Savings Taxation Directive in the European Union (EU). ${ }^{4}$ EU-Member States and fifteen other countries introduced a system to ensure taxation of foreign interest income of domestic households according to domestic tax rules. Although not a co-ordination of tax rates, the system is however a means to reduce tax evasion by enabling residence-based taxation of (part of) households' capital income. It can be seen as a procedural arrangement that ultimately aims at exchanging information in order to allow taxation according to the residence principle. The Directive is therefore expected to increase tax compliance. Three years after the introduction of the Directive, the first review of the legislation was prepared by the European Commission and published in September 2008. ${ }^{5}$ The review led also to a proposal for amendments of the current Directive whose objectives have been supported by the Council of Finance Ministers (ECOFIN) in December $2008 .^{6}$

This paper provides an analysis of the functioning of Council Directive 2003/48/EC on taxation of savings income in the form of interest payments. It analyses the evolution of

\footnotetext{
${ }^{2}$ See Fuest, Huber and Mintz (2005) and Nicodème (2007) for surveys of the tax competition literature.

${ }^{3}$ Edwards and Keen (1996) show that co-operation is not necessarily welfare enhancing if the assumption of a benevolent state is relaxed. The idea for negative welfare effects of tax co-ordination was already made by Brennan and Buchanan (1980) in its most drastic form: The government only maximizes its own utility; the utility of households disappears in the objective function.

${ }^{4}$ The title of the legal document is "Council Directive 2003/48/EC of 3rd June 2003 on taxation of savings income in the form of interest payments". The national implementing measures came simultaneously into application on July $1^{\text {st }} 2005$

${ }^{5}$ European Commission, COM(2008) 552

${ }^{6}$ The political support for amendments to the Directive has been increased by recent prominent tax evasion cases in countries such as Liechtenstein.
} 
certain proceeds from investments that are covered by the Directive or that contain elements falling within its scope. In addition, the analysis looks at the effects of the implementation of the Directive on investment patterns ${ }^{7}$.

The data suggest that the Savings Taxation Directive had no measurable effects on the development of different investments that fall under the scope of the Directive. At a first glance, this is surprising since the expected tax increase due to the Directive should lead to economic reactions. A possible reason for this surprising result is that the existence of loopholes makes it easy for investors to circumvent taxation on foreign-source interest. ${ }^{8}$ Furthermore, the countries where most of the international deposits are held (Switzerland and Luxemburg) did not exchange information, but levied a withholding tax with a relatively low rate of 15 percent in the period surveyed in this paper. Generally, the analysis of the effects of the Savings Taxation Directive faces some shortcomings linked to definitions in the legal provisions of the Directive, to data limitations and to technical issues, all of which make an assessment of the Directive more difficult. The issues linked to the legal provisions include the facts that the beneficial owner may use intermediate structures not covered by the Directive or that the country of the paying agent may be different from the country where the funds are located. Finally, the analysis is also constrained by the difficulty of separating many concomitant effects. The Directive is aimed at enabling Member States to tax their resident individuals on interest income received in another Member State. To the extent that the income covered by the Directive previously escaped taxation, there is likely to be an effect on the vehicles that fall within its scope: investors might decrease their savings because of a lower net-of-tax interest rate; investors might reallocate their savings in the same vehicle but in another country (e.g. one not subject to the Directive); investors might reallocate their savings towards other investment vehicles as the relative net-of-tax return has changed; and

\footnotetext{
${ }^{7}$ It has to be mentioned that for many of these instruments the data availability is weak, which leaves us with a
} 
(or) investors might evade taxation. This and the different data limitations mentioned above must be borne in mind when interpreting the results of the analysis.

In the remainder of the paper, section 2 gives a brief overview of the functioning, the detected loopholes, and the proposed amendments of the Savings Taxation Directive. Section 3 gives a brief overview of the literature in this field. In Section 4 we explore different data sources to give an impression on the effects of the Savings Taxation Directive. Section 4 is organised as follows: the next sub-section looks at the evolution of interest payments in general. The third sub-section looks at the evolution of bank deposits. Next, the data collected from the Member States on exchange of information and withholding taxes is analysed. The last subsection offers a statistical analysis of the impact of the introduction of the Directive on savings and on bank deposits. Section 5 concludes.

\section{The functioning of the Savings Taxation Directive}

\subsection{Current Regulation and Loopholes}

The Savings Taxation Directive has one particular goal: to allow EU Member States to tax the foreign interest income of their resident individuals. This goal shall ideally be reached by an automated information exchange between Member States. However, for a transitional period, three Member States - Austria, Belgium and Luxembourg - do not exchange information, but levy a withholding tax instead. 75 percent of the revenue from the withholding tax is then shared with the country of residence of the beneficial owner. The end of the transitional period is not fixed and depends on the agreement of third countries to establish an information exchange relationships with EU Member States.

Information is exchanged (or a withholding tax is levied) when different criteria are fulfilled. Firstly, the beneficial owner of a payment must be a resident of an EU country.

${ }^{8}$ For a discussion of legal loopholes see Gläser (2007) and Jiménez (2006). 
Secondly, the payments must fall under the scope of the Directive. The Directive defines interest as "interest paid or credited to an account, relating to debt claims of every kind, whether or not secured by mortgage and whether or not carrying a right to participate in the debtor's profits, and, in particular, income from government securities and income from bonds or debentures, including premiums and prizes attaching to such securities, bonds or debentures; penalty charges for late payments shall not be regarded as interest payments." This definition corresponds to the OECD definition of interest. ${ }^{9}$ However, the Directive adds three more categories to the OECD definition and is therefore somewhat broader than the international definition of interest payments. ${ }^{10}$ Furthermore, the Directive has foreseen a transitional regime for some negotiable debt securities. This so-called "grandfathering" of certain securities will be discussed in section 3. Finally, the information about the sum of the payments made, the name and address of the beneficial owner are sent by financial intermediaries ("paying agents" in the legal language of the Directive) to their national authorities. They collect the data, prepare it and send it to the country of residence of the beneficial owner where the interest can be taxed according to the national tax rules.

The current regulation is criticized by some authors because of loopholes and possible legal shortcomings. The existing problems identified by Jiménez (2006) Gläser (2007), and Gläser and Halla (2008) can be summarized by the following three points:

(a) Paying agents and the Geographical scope of the Directive

Paying agents are normally economic operators that pay or secure interest for the immediate benefit of the beneficial owner. In general, this is the bank charged by the beneficiary of managing his savings. The territorial scope of the Directive is limited to the European Union, and agreements for equivalent or similar measures have a coverage limited

\footnotetext{
${ }^{9}$ The definition of interest used by the OECD can be found in Article 11 in the condensed version of the "Model Tax Convention on Income and Capital", which can be found online at http://www.oecd.org/dataoecd/14/32/41147804.pdf (January 28, 2009).
} 
to five third countries (Andorra, Liechtenstein, Monaco, San Marino, Switzerland) and ten dependent and associated territories (Aruba, Anguilla, Guernsey, Jersey, the Isle of Man, Cayman Islands, British Virgin Islands, Netherland Antilles, Montserrat, Turks and Caicos Islands). It is therefore clear that investors will still be able to evade taxes by shifting their funds to banks and other intermediaries located in tax havens and financial centres that do not fall under the scope of the directive and its related agreements. Hence, these jurisdictions do not ensure either a minimum level of taxation or an exchange of information on income paid to non-residents. The most frequently-mentioned examples are Hong Kong, Dubai, Panama, Singapore, and Macao. Tax evasion by using financial intermediaries that reside in these countries can be relatively easy.

(b) Beneficial owner.

The beneficial owner is "any individual who receives an interest payment or any individual for whom an interest payment is secured" (Art. 2(1) Savings Taxation Directive). The definition covers only payments made for the immediate benefit of individuals. The definition applies therefore only to individuals but not to companies or other legal persons, nor to those legal arrangements (e.g.: "discretionary" trusts) for which assets and income are not immediately entitled to any beneficial owner. An easy way of circumventing the current Directive is therefore to carry out interest payments using an interposed legal person or arrangement. In this case the Savings Taxation Directive does not apply. This is another way for circumventing taxation under the Directive.

(c) Definition of Interest Income.

Despite the fact that the concept of interest in the directive is broader than in international tax law and in most Member States' domestic legislation, the current version of the Directive still does not cover income from other forms of saving like innovative financial

\footnotetext{
${ }^{10}$ The detailed list of all payments under the scope of the Directive is given in Article 6.1b, c, and d of the Directive. Jiménez (2006) discusses this definition in detail.
} 
products with capital protection and life insurance products. This could have led to distortions in the choice of households between different savings instruments.

\subsection{Proposed Amendments}

The Savings Taxation Directive in its current version has left loopholes for investors to avoid the application of information exchange or a withholding tax. For this reason the European Commission proposed amendments of the Directive which aim at closing the loopholes presented above. With regard to the beneficial owner, the proposed changes are supposed to identify and cover interest payments which are channelled through intermediate tax-exempted structures like non-charitable trusts or foundations established outside the EU. This is assumed to solve the problem that beneficial owners could use these legal persons and arrangements to circumvent the Directive. By applying a "look-through" approach based on information that is already available thanks to the application the Anti-Money-Laundering Directive $^{11}$, the beneficial could be identified even though legal entities and arrangements are interposed.

The proposed amendments also foresee a change in the definition of the "paying agent" (financial intermediary), in order to cover interest payments channelled through intermediate tax-exempted structures like non-charitable trusts or foundations established inside the EU. As seen above, the paying agent is usually defined as the bank or other intermediary that pays interest to the owner. In the case where the interest is not paid directly to the owner but instead to another entity or arrangement, there is currently room for abuse and distortions when these entities or arrangements do not pay out income in the form of interest and are not treated as paying agents upon receipt. This is similar to the loophole described above since the paying agents upon receipt are currently not clearly defined. According to the 2008 proposal, these entities and arrangement having to act as paying agents

\footnotetext{
${ }^{11}$ Directive 2005/60/EC of the European Parliament and of the Council of 26 October 2005 on the prevention of the use of the financial system fort he purpose of money laundering and terrorist financing.
} 
upon receipt should be clearly defined and they should apply the provisions of the Directive when the beneficial owner of the interest they receive is resident in another EU-Member State. Finally, the proposal seeks to extend the scope of the Directive to income obtained from investments in some innovative financial products with capital protection and life insurance products. These products are supposed to be similar to savings instruments already covered by the Directive and the proposal add therefore them to the scope in order to avoid distortions in the choices made by the investors.

\section{Literature}

The literature on the Savings Taxation Directive can be divided in three strands: theoretical, legal and empirical contributions. While the theoretical literature deals so far only with the question as whether countries opt for an information exchange or a withholding tax and what determinants influence this decision, the legal part of the literature deals with the functioning of the current form of the Savings Taxation Directive and identifies loopholes of the system. The empirical part of the literature is only evolving now. The theoretical studies analyze mainly the incentives of countries to share information voluntarily and what role revenue sharing might play to make information sharing more attractive to other. An excellent survey by Keen and Ligthart (2006a) discusses the relevant literature in this field. ${ }^{12}$

So far there is almost no literature that empirically evaluates the Savings Taxation Directive directly. One exception is Klautke and Weichenrieder (2008). The authors analyze a specific loophole of the Directive due to grandfathering. They argue that there should be a difference in the rate of return for bonds that were issued under the scope of the Directive and for bonds that were issued before (and which are grandfathered). However, their study finds no significant effects for the difference in the rates of return on those two assets. Their conclusion is that the Savings Taxation Directive offers so many other loopholes that the 
grandfathering regulation is actually not changing rates of return since there are many other options for tax evasion. The other exception is Johannesen (2009) who uses bilateral data on external deposits from the BIS ${ }^{13}$ and finds that the Directive had a significant negative effect on the depositing of EU residents in some external countries, notably Switzerland, but no evidence of a change towards increased depositing in countries outside of the scope of the Directive.

Additionally, Huizinga and Nicodème (2004) provide a contribution that is not directly related to the Savings Taxation Directive but to the determinants of international deposits. They show that foreign deposits do react to taxation and also to information sharing. Since income from interest from deposits is covered by the Directive, the results of their paper suggest that the introduction of the Directive should have led to changes in international depositing. Finally, a recent empirical paper by Ligthart and Voget (2008) deals the determinants driving governments' decisions to share information bilaterally. The authors use data from the Dutch Ministry of Finance and show that the willingness to share information depends on the domestic income tax rate, the size of the marginal cost of public funds, as well the share of a country's interest-bearing deposits held abroad. Interestingly, information sharing is shown to be reciprocal in most cases.

The next section will present data on the Savings Directive including data on deposit held by foreigners, the amounts of interested payments reported in information exchange and the withholding tax revenue shared between countries.

\footnotetext{
12 The most important contributions are Bacchetta and Espinosa (1995) and (2000), Eggert and Kolmar (2002) and (2004), Huizinga and Nielsen (2003) and Keen and Ligthart (2006b and 2007).

13 See section 4.2 for a discussion of the pros and cons of these data. One potential shortcoming is that the data mixes deposits by individuals and by corporations.
} 


\section{Evidence from different data sources}

\subsection{Sectoral account data}

A first step in the analysis is to use Eurostat's sectoral accounts data to follow the evolution of interest payments vis-à-vis other types of savings income and the evolution of household recipients vis-à-vis financial and non-financial corporate recipients. Two caveats shall be made. First, missing data do not allow the calculation of summary time-series for years before 2000 and for seven Member States. Secondly, it should be noted that the Eurostat data include many interest payments that do not fall under the scope of the Directive (for example, domestic interest payments). However, those figures may give some indications about the relative importance of interest income in comparison to other types of savings income and about the general evolution of income from savings.

The figures for interest and dividends are reported in Table (1). First, columns (1) and (2) of Table (1) show that gross savings ${ }^{14}$ have been relatively stable in percentage of GDP, while the amount of income from savings ${ }^{15}$ in percentage of GDP has followed a U-curve between 2000 and 2006. A noticeable element from columns (3) and (4) is the steady decrease of the share of interest income in total income from savings between 2000 and 2005, matched by an increase in the share of dividends. This situation might be explained by relatively low interest rates, causing interest-bearing instruments to be less attractive compared to stocks for example.

\footnotetext{
${ }^{14}$ This is category B8G of the Eurostat sectoral accounts. A finer distinction between savings from households and from corporations is not feasible because of poor data availability

${ }^{15}$ Category d4 of the sectoral accounts. This category represents 'property income', which is arguably larger than savings income and includes interest (d41), distributed income of corporations (d42), reinvested earnings on direct foreign investment (d43), property income attributed to insurance policy holders (d44), and rents (d45).
} 
Table 1: Summary figures for various types of income from savings and recipients

\begin{tabular}{|c|c|c|c|c|}
\hline Year & $\begin{array}{c}\text { (1) } \\
\text { Gross savings to GDP }\end{array}$ & $\begin{array}{c}\text { (2) } \\
\text { Savings income to GDP }\end{array}$ & $\begin{array}{l}\text { (3) } \\
\text { Share of interest } \\
\text { income in total } \\
\text { savings income }\end{array}$ & $\begin{array}{c}\text { (4) } \\
\text { Share of dividend } \\
\text { income in total savings } \\
\text { income }\end{array}$ \\
\hline 2000 & $20.4 \%$ & $35.5 \%$ & $60.6 \%$ & $29.9 \%$ \\
\hline 2001 & $20.1 \%$ & $35.7 \%$ & $60.2 \%$ & $31.9 \%$ \\
\hline 2002 & $19.8 \%$ & $31.6 \%$ & $58.1 \%$ & $33.3 \%$ \\
\hline 2003 & $19.6 \%$ & $29.8 \%$ & $55.4 \%$ & $35.7 \%$ \\
\hline 2004 & $20.2 \%$ & $30.4 \%$ & $53.2 \%$ & $36.4 \%$ \\
\hline 2005 & $19.8 \%$ & $32.4 \%$ & $53.0 \%$ & $37.0 \%$ \\
\hline 2006 & $20.2 \%$ & $35.4 \%$ & $55.7 \%$ & $35.1 \%$ \\
\hline & $\begin{array}{c}\text { (5) } \\
\text { Share of interest } \\
\text { income of Households } \\
\text { in total interest income }\end{array}$ & $\begin{array}{c}\text { (6) } \\
\text { Share of dividend } \\
\text { income of Households in } \\
\text { total dividend income }\end{array}$ & $\begin{array}{c}\text { (7) } \\
\text { Share of interest } \\
\text { income in Households' } \\
\text { total savings income }\end{array}$ & $\begin{array}{c}\text { (8) } \\
\text { Share of dividend } \\
\text { income in Households' } \\
\text { total savings income }\end{array}$ \\
\hline 2000 & $20.0 \%$ & $52.8 \%$ & $33.9 \%$ & $42.6 \%$ \\
\hline 2001 & $19.6 \%$ & $51.1 \%$ & $33.4 \%$ & $44.0 \%$ \\
\hline 2002 & $19.4 \%$ & $51.2 \%$ & $30.8 \%$ & $45.1 \%$ \\
\hline 2003 & $19.7 \%$ & $51.8 \%$ & $28.9 \%$ & $46.7 \%$ \\
\hline 2004 & $19.4 \%$ & $51.3 \%$ & $28.0 \%$ & $48.2 \%$ \\
\hline 2005 & $18.1 \%$ & $49.7 \%$ & $27.0 \%$ & $48.9 \%$ \\
\hline 2006 & $16.9 \%$ & $48.8 \%$ & $28.2 \%$ & $47.8 \%$ \\
\hline
\end{tabular}

Second, columns (5) and (6) show that the share of household recipients in both total interest payments received and total dividends received is relatively stable between 2000 and 2004 and drops in 2005 and 2006. A finer analysis shows that this drop is due to an increase in payments received by financial corporations. Figure (1) illustrates this for interest payments.

Figure 1: Total interest payments received

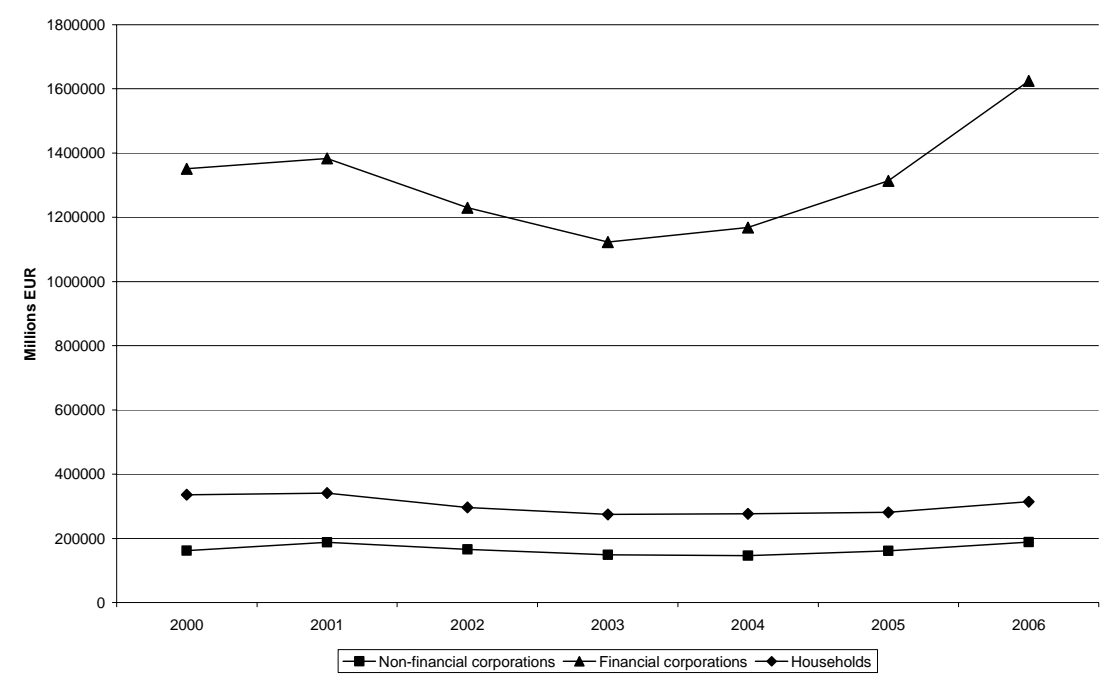

20 EU Member States (series incomplete or not available for Bulgaria, Cyprus, Hungary, Lithuania, Malta, Romania, and Sweden). Data for Greece (2005 and 2006) are set as in 2004. Data for Ireland (2000 and 2001) are set as for 2002. Data for Poland, Portugal and Latvia (2006) are set as for 2005. Source: Eurostat Sectoral data. 
Finally, columns (7) and (8) display the share of interest and of dividends in households' total income from savings. The figures show that there has been a gradual shift from interest toward dividend revenue between 2000 and $2004^{16}$. Nevertheless a significant share of savings income is still made of interest income. This evolution is shown in figure (2). In conclusion, the introduction of the Directive does not appear to have led to major changes in the composition of savings incomes of European households.

Figure 2: Composition of income from savings for households

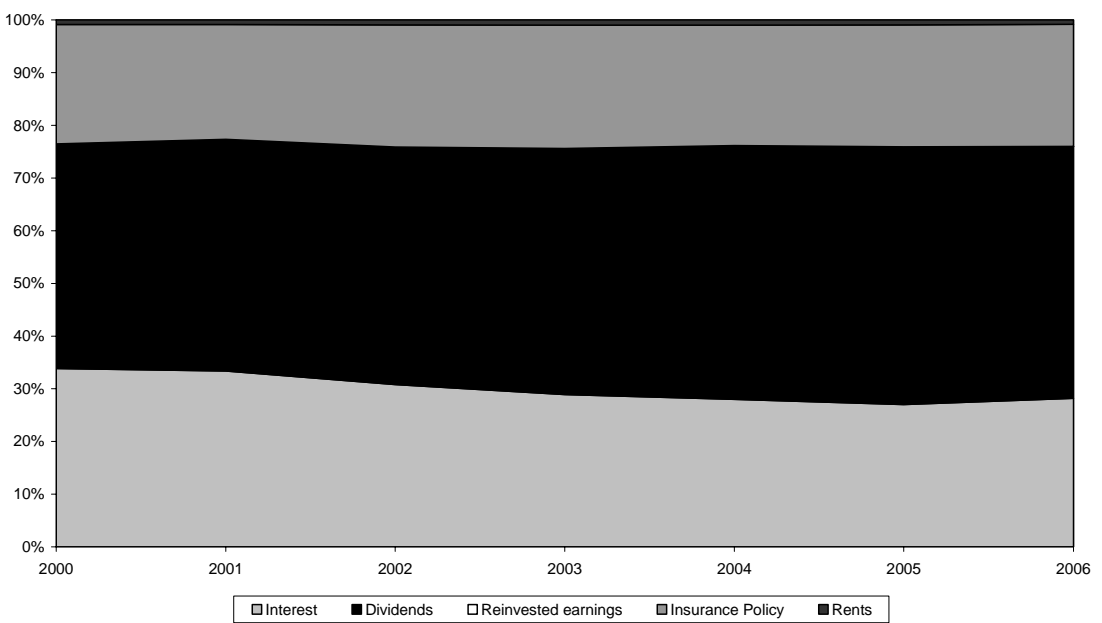

GDP-weighted averages for 20 EU Member States (series incomplete or not available for Bulgaria, Cyprus, Hungary, Lithuania, Malta, Romania, and Sweden). Data for Greece (2005 and 2006) are set as in 2004. Data for Ireland (2000 and 2001) are set as for 2002. Data for Poland, Portugal and Latvia (2006) are set as for 2005. Source: Eurostat sectoral data.

\subsection{BIS data}

\subsubsection{The BIS bilateral data on international deposits}

This section investigates the possible effect of the Directive on international depositing. To this end, bilateral data from the Bank for International Settlements (BIS) on deposits from foreign bank and foreign non-bank depositors are used. Non-Bank depositors are all depositors which are either individuals or companies excluding banks. Deposits held by this group are called "non-bank deposits" in the following analysis. If the depositor is a bank the name of the deposit is accordingly "bank deposits". The quarterly data cover the

\footnotetext{
${ }^{16}$ The remaining categories are property income attributed to insurance policy holders (d44) and rents (d45). Both are stable at respectively about $23 \%$ and $1 \%$ of the total revenues from savings. The category reinvested earnings (d43) is zero for households recipients.
} 
period Q1-2000 to Q4-2007. The data concern deposits in all currencies and are expressed in (million of) USD. To measure the effects it is also necessary to take into account the agreements concluded with five European third countries on equivalent measures to the Directive and with ten dependent and associated territories of the EU Member States on the same measures.

As a first step, data for BIS reporting countries referring to payments made crossborder to depositors in a EU Member State has been selected. It should be noted that not all EU Member States report to the BIS and that, therefore, the coverage is incomplete. Next, the data for the BIS reporting countries where the deposits are located have been divided into three categories ${ }^{17}$ :

(a) EU Member States and third countries or jurisdictions that apply a withholding tax to interest paid to individuals who are residents of a Member State. This category includes Austria, Belgium, Luxembourg, as well as Guernsey, Jersey, Isle of Man and Switzerland.

(b) EU Member States that exchange information under the Directive. This category includes: Germany, Spain, Finland, France, Ireland, Italy, the Netherlands, Portugal, Sweden and the United Kingdom.

(c) Finally, other jurisdictions that do not apply the Directive. This category includes: Australia, Canada, India, Japan, Turkey, Taiwan and the United States.

\subsubsection{Data limitations}

There are several problems inherent in the data. Firstly, two statistical breaks in reporting have a large impact on the totals. This is especially the case for the $1^{\text {st }}$ quarter of

\footnotetext{
${ }^{17}$ Because of substantial gaps in the information for the whole period, the observations for Bermuda, Brazil, Chile, Denmark, Greece, Mexico and Panama, have not been taken into account in the summary statistics, as they would distort the picture across years. Finally, Singapore and Macao have not agreed to disclose their bilateral data for the purpose of this study.
} 
2003 and for the $2^{\text {nd }}$ quarter of 2006 for which large structural breaks appear for deposits by UK residents in the US. This break increases the share of non-bank deposits in the US substantially which in turn leads to a strong increase in the share of third countries which do not apply the Directive. Secondly, all currencies are expressed in USD. Exchange rates with the USD have been volatile throughout the period and this may affect some data. Thirdly, non-bank deposit data include both individual depositors (subject to the Directive) and corporate depositors (not subject to the Directive). There is no information on the exact split between the two types of depositor. One indication is that, as reported in a previous section, the total amount of interest income received by households in the total amount of interest income received by all private recipients was $16.9 \%$ in 2006 . This share may vary across countries and years and there is unfortunately no proper way to deal with this problem in the context of this analysis.

\subsubsection{Analysis}

At the end of 2007, external non-bank deposits amounted to USD 627.6 billion for the countries applying a withholding tax (category (a) above); to USD 1,203.8 billion for Member States applying information exchange (category (b) above); and to USD 538.415 billion for third countries (category (c) above).

First, the quarterly growth rate of non-bank deposits for all three categories has been computed and is illustrated in figure (3). Because of the structural breaks, data for Q1-2003 and Q2-2006 for third countries (category (c)) are not included ${ }^{18}$. A visual analysis of figure (3) does not allow detection of a common pattern for the growth of non-bank deposits in the countries covered by the savings taxation measures (categories (a) and (b)) compared to the third countries (category (c)). ${ }^{19}$ A difference between third countries (category (c)) and countries that applied the Directive (categories (a) and (b)) is that the volatility of growth

\footnotetext{
18 There are two major statistical breaks in the first quarter of 2003 and the second quarter of 2006. Those statistical breaks inflate the share of third countries at the expense of other categories.
} 
rates is much larger for the former until 2004. After that point in time the development is similar. This holds also for the years after the introduction of the Directive.

Figure 3: Quarterly growth of non-bank deposits

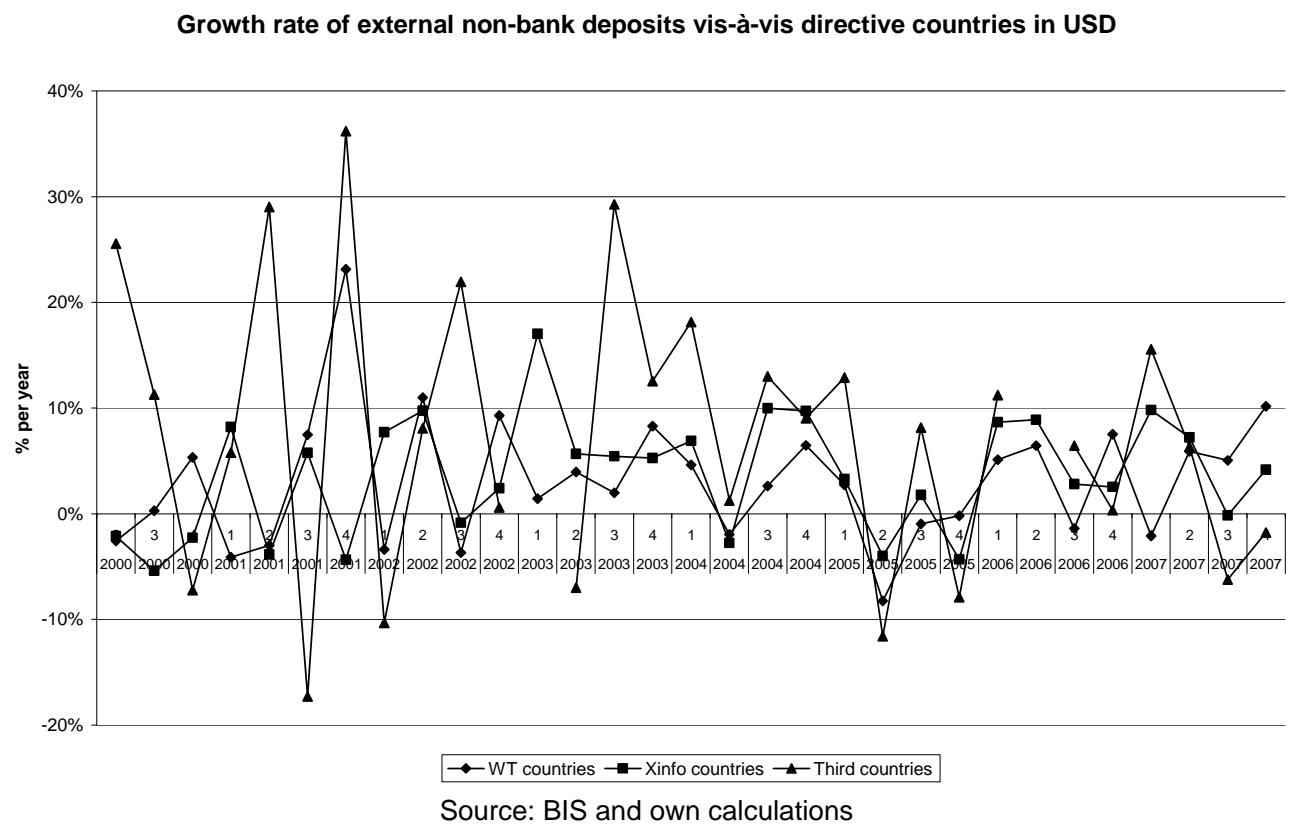

Next, for each category ((a), (b) and (c) above) of BIS reporting countries, the evolution of the share in the total external non-bank deposits made by residents in countries in category (a) and (b) has been studied. ${ }^{20}$ Notwithstanding the two structural breaks mentioned above ${ }^{21}$, figure (4) shows that the share of deposits in banks in BIS reporting countries that apply the withholding tax (category (a)) has decreased from 35.0\% to 29.3\% between mid-2003 and mid-2005 but has been stable after the introduction of the directive. This was mainly to the benefit of third countries (category (c)). The respective shares of each category of BIS reporting countries have been relatively constant since mid-2005. The same pattern emerges if the deposits are converted from US-Dollars to Euro. This is done in order to control for possible distortions due to the reporting in US-Dollars only and the volatility of

\footnotetext{
${ }^{19}$ Controlling for the exchange rate does not change the conclusions.

20 i.e. the 13 EU Member States that report to the BIS.

${ }^{21}$ Therefore, the shares from the fourth quarter of 2002 cannot be directly compared with the shares of the second quarter of 2003, and the shares of the first and third quarters of 2003 cannot be directly compared either.
} 
Dollar-Euro exchange rate. The only major difference in this case is that the share of third countries is larger. However, the general trend does not change.

Figure 4: Share of BIS reporting countries by category in non-bank deposits

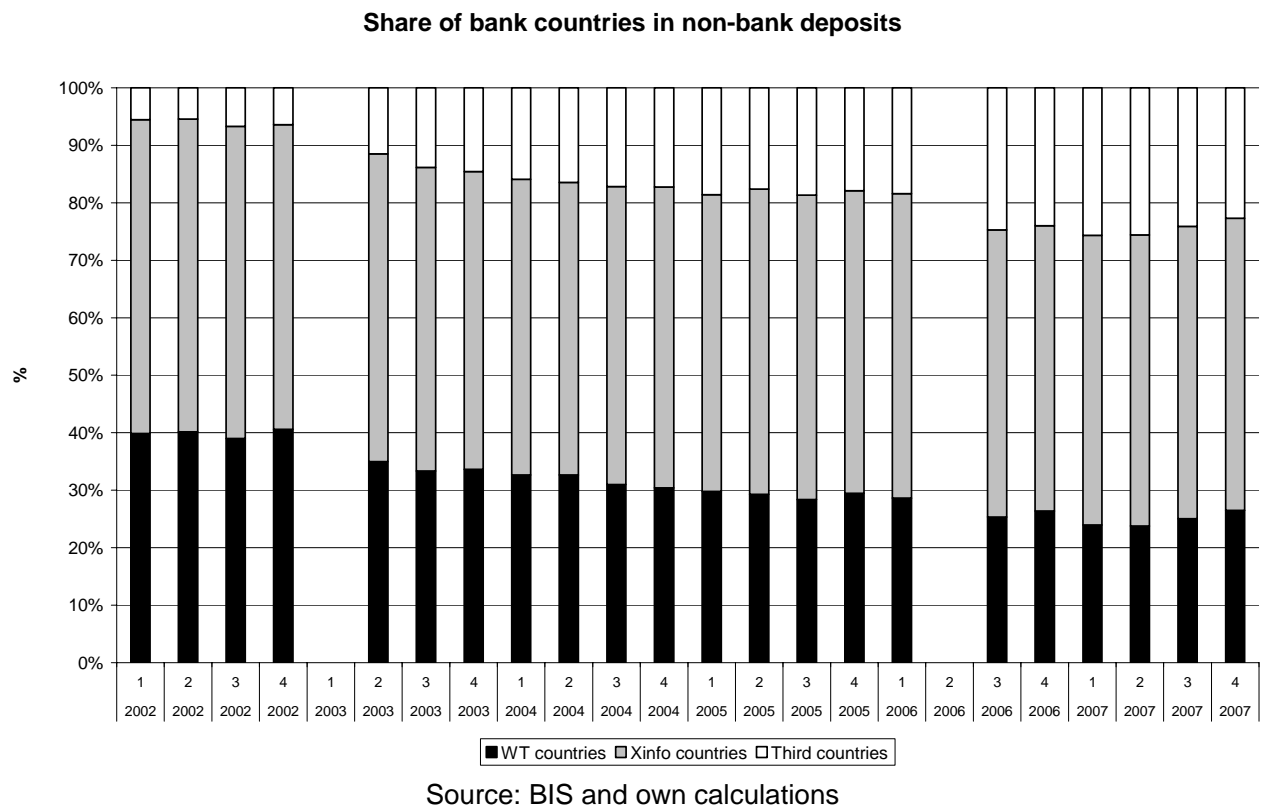

Finally, we can compare the previous data with the share of external deposits from bank depositors. This is done in figure (5). We see that the lion's share (about 70\%) is for countries that apply information exchange and that the shares are stable over time. The large share of countries exchanging information (category (b)) reflects the fact that countries that host large financial sectors (such as the UK and Germany) belong to this group. As regards the share of non-bank deposits two observations can be made. First, from a static point-ofview the share of external non-bank deposits in countries applying the withholding tax and in third countries (categories (a) and (c)) is about 35\% of total external deposits, while this proportion is $20 \%$ in countries applying exchange of information (category (b)). Secondly, from a dynamic point of view, while the share of deposits made by external banks has not changed, there has been a slight decrease in the share of non-bank deposits in countries exchanging information (category (b)). These two elements could suggest that non-bank depositors have a preference for countries maintaining some form of bank secrecy. 
In conclusion, for deposits of non-bank depositors, there has been an observable shift from countries within the scope of the Directive towards third countries. However, this development took place before the Directive came into force. Nevertheless, the anticipation of measure against tax evasion might have induced some investors to shift their deposits.

Figure 5: Share of BIS reporting countries in bank deposits

Share of bank countries in bank deposits

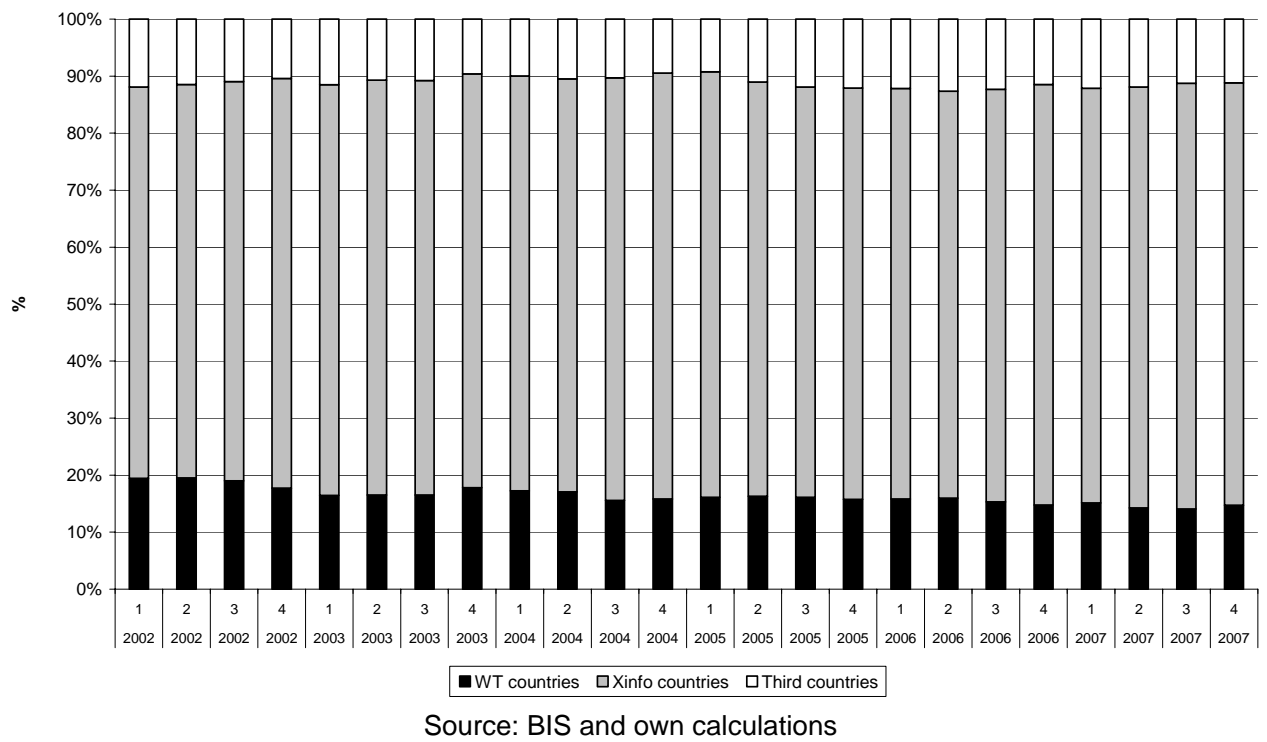

4.3. Evolution of information exchange and withholding taxes using data from Member States and from other jurisdictions covered by the savings agreements

\subsubsection{Description of the data}

The EU Member States and other jurisdictions covered by the savings taxation measures deliver data on the information shared and on the tax revenue received from or paid to other countries. This data is available for the second half of 2005 and for $2006{ }^{22}$ The data only contain information on payments covered by (and reported under) the Directive:

- The amount of withholding tax collected by countries that do not share information. The amount is split by the country of the recipient of the tax payment.

\footnotetext{
${ }^{22}$ Note that the UK is a special case because its tax year ends on $6^{\text {th }}$ April, so its data refers to the period between $1^{\text {st }}$ July 2005 and $5^{\text {th }}$ April 2006 for 2005 and $6^{\text {th }}$ April 2006 to $5^{\text {th }}$ April 2007 for 2007.
} 
However, there is no information about the number of beneficial owners concerned except for the case when beneficial owners opt for voluntary disclosure of payments. This is at this point in time only possible in Luxembourg.

- $\quad$ The amount of interest payments and sales proceeds sent (bilateral data), if possible with a breakdown between interest payments and sales proceeds, as well as a breakdown between beneficial owners and residual entities.

- The amount of interest payments or sales proceeds by type (debt claims, interest accrued or capitalised coming from sales of debt claims or undertakings, interest from undertakings, annualised interest).

- The number of beneficial owners on a bilateral basis, the number of residual entities on a bilateral basis, the number of paying agents, and the number of records exchanged between countries.

\subsubsection{Data Limitations}

Starting an international information exchange system is a challenging task. One can expect that the coherent application of a new set of rules for information exchange in $27 \mathrm{EU}-$ countries is not easily established. In fact, data delivery and quality turned out to be difficult. One reason for this is that countries can choose to report different sorts of data. This will be discussed in detail in section 4.3.3. In general, the data from the member states shows only the amount of information exchanged or withholding tax collected. It is difficult to estimate, how much income was shifted to tax havens that not operate under the directive or that was shifted back to the domestic country. The following descriptive explanations have to be read in the light of this. 


\subsubsection{Descriptive data analysis}

As pointed out above, the main aim of the Directive is to enable Member States to tax interest income received by their resident individuals from other Member States through an exchange of information. During a transitional period some of the Member States (Austria, Belgium, and Luxemburg) levy a withholding tax instead of exchanging information. The revenue from this tax is shared with the Member State of residence of the beneficial owner of the interest income. The agreements with the third countries and the other jurisdictions build on either of these two methods but in most cases they are unilateral in the sense that information is given to Member States (Anguilla and Cayman Islands) or the withholding tax levied is shared with Member States (Andorra, Liechtenstein, Monaco, San Marino, Switzerland, and Turks \& Caicos Islands). Only Montserrat and Aruba (which apply reporting) and Jersey, Guernsey, Isle of Man, British Virgin Islands and the Netherlands Antilles (which levy a withholding tax) in their turn receive, from Member States, information or a share of the withholding tax levied.

In the following section available data on interest payments and sales proceeds reported or the amount of withholding tax shared is briefly described.

\section{a. Countries operating information exchange system}

The first group of countries is exchanging information as provided in Articles 8 and 9 of the Directive or under the respective Agreement. As mentioned above, countries can choose between two ways of reporting. They can either choose to restrict the minimum amount of information reported by paying agents to the total amount of interest or income and to the total amount of the proceed from the sale, redemption or refund (Article 8 (2), last paragraph) or by the type of interests as defined in Article 8 (2) (a) to (e). One problem is that these two datasets do not necessarily match. Some Member States reported both values with, in some cases, differences between them. We report both data sources but stress this caveat. In comparison with data from Article 8 (2) last paragraph, this might be used as an indicator 
for the quality of data treatment in national tax authorities. In the optimum, the sum of data delivered to all countries should equal the sum of all payments received from national tax authorities. As mentioned this is not yet the case. For some countries which delivered both values there are some large discrepancies.

Table (2) shows the countries that apply an information exchange regime and the sum of reported interest payments and sales proceeds according to Article 8 (2) last paragraph. As expected, the largest economies hosting a large part of economic activities and financial centres report the highest values. In 2006, Germany sent information on interest payments amounting to almost 1.4bn Euro which decreased to 0.94 in 2007. Similar values (1.6bn Euro in 2006 and 1.2bn Euro in 2007) can be found in Italy. France reported payments of 2.0bn Euro and 2.5bn Euro to other countries in 2006 and 2007 respectively. An extremely high value interest payments reported was reported from the UK (9.1bn Euro) for 2005.

A special case is the value for Luxembourg. As explained above, beneficial owners can opt for voluntary disclosure in Luxembourg. These voluntary disclosed values amount to more than 4bn Euro in 2006 and above 1.1bn in the second half of 2005. One reason for these high values might be the amnesty for tax evasion which was offered in Germany from 31 December 2003 until April 1 2005. Tax payers with foreign deposits that opted for the amnesty would also chose voluntary disclosure since the information was already disclosed to German tax authorities.

\begin{tabular}{lrrr} 
Table 2: Interest payments and sales proceeds reported by countries using information exchange* \\
\hline EU Member States & $\mathbf{2 0 0 5}$ (2nd half) & $\mathbf{2 0 0 6}$ & $\mathbf{2 0 0 7}$ \\
Austria & n.a. & n.a. & n.a. \\
Belgium & n.a. & n.a. & n.a. \\
Bulgaria* $^{* *}$ & - & - & n.a. \\
Cyprus & 5.26 & 15.05 & 25.41 \\
Czech Republic & 2.92 & 17.81 & 26.75 \\
Germany & 660.73 & 1392.06 & 942.09 \\
Denmark & n.a. & 1.16 & 693.10 \\
Estonia & n.a. & 4.40 & n.a. \\
Spain & 488.11 & 423.42 & 256.52 \\
Finland & 26.02 & 60.93 & n.a.
\end{tabular}




\begin{tabular}{|c|c|c|c|}
\hline France & 568.14 & 2020.04 & 2485.40 \\
\hline Greece & 6.85 & 23.11 & 1.00 \\
\hline Hungary & n.a. & n.a. & n.a. \\
\hline Ireland & 258.88 & 771.00 & 1901.24 \\
\hline Italy & 280.53 & 1615.92 & 1210.35 \\
\hline Lithuania & n.a. & 0.09 & n.a. \\
\hline Latvia & 0.18 & 0.65 & n.a. \\
\hline Luxembourg & 1119.79 & 4188.68 & 6344.34 \\
\hline Malta & 1.02 & 2.10 & n.a. \\
\hline Netherlands & 107.83 & 800.14 & n.a. \\
\hline Poland & 0.00 & 0.71 & 10.00 \\
\hline Portugal & n.a. & 0.56 & 5.18 \\
\hline Romania** & - & - & 7.34 \\
\hline Sweden & n.a. & n.a. & n.a. \\
\hline Slovenia & 0.59 & 1.35 & n.a. \\
\hline Slovakia & 1.87 & 4.76 & n.a. \\
\hline United Kingdom & 9132.49 & n.a. & n.a. \\
\hline \multicolumn{4}{|l|}{ Third Countries } \\
\hline Switzerland & 70.50 & 549.12 & 500.89 \\
\hline \multicolumn{4}{|c|}{ Dependent and Associated Territories } \\
\hline Anguilla & n.a. & n.a. & n.a. \\
\hline Aruba & 0.01 & 0.09 & n.a. \\
\hline Cayman Islands & 8.81 & 18.02 & n.a. \\
\hline Netherlands Antilles & n.a. & 0.05 & n.a. \\
\hline Montserrat & n.a. & n.a. & n.a. \\
\hline
\end{tabular}

${ }^{*}$ Amount of interest payments and sales proceeds under Art. 9 subject to exchange of information/ voluntary disclusore, (Beneficial owners and residual entities) reported accorsing to Art. 8(2) last paragraph.

**Bulgaria and Romania joined the EU in 2007 therefore no data is available for 2005 and 2006

Table (3) shows the figures reported according to Article 8 (2) (a) to (e). Since most countries reported only values according to Article 8 (2) last paragraph, there are many missing values. We report only the countries that send indeed values. The only country that did not report any values is Sweden.

\begin{tabular}{|c|c|c|c|}
\hline EU Member States & 2005 (2nd half) & 2006 & 2007 \\
\hline Austria & n.a. & n.a. & n.a. \\
\hline Belgium & n.a. & n.a. & n.a. \\
\hline Bulgaria** & - & - & 1.54 \\
\hline Cyprus & 5.23 & 15.04 & 25.44 \\
\hline Czech Republic & n.a. & n.a. & 69.21 \\
\hline Germany & n.a. & n.a. & n.a. \\
\hline Denmark & n.a. & 415.31 & 690.16 \\
\hline Estonia & n.a. & n.a. & 0.74 \\
\hline Greece & 1.10 & 3.95 & 7.04 \\
\hline Spain & 487.82 & 419.51 & 256.52 \\
\hline
\end{tabular}




\begin{tabular}{|c|c|c|c|}
\hline Finland & n.a. & n.a. & n.a. \\
\hline France & n.a. & n.a. & n.a. \\
\hline Hungary & 62.03 & 5.22 & 6.60 \\
\hline Ireland & n.a. & n.a. & n.a. \\
\hline Italy & n.a. & n.a. & n.a. \\
\hline Lithuania & 0.09 & 0.09 & 0.18 \\
\hline Luxembourg & n.a. & n.a. & n.a. \\
\hline Latvia & 0.18 & 0.66 & n.a. \\
\hline Malta & 1.02 & 2.11 & n.a. \\
\hline Netherlands & 320.65 & 816.22 & 370.26 \\
\hline Poland & 4.84 & 15.40 & 7.93 \\
\hline Portugal & n.a. & n.a. & n.a. \\
\hline Romania** & - & - & n.a. \\
\hline Sweden & n.a. & n.a. & n.a. \\
\hline Slovenia & 0.59 & 1.35 & 1.95 \\
\hline Slovakia & n.a. & n.a. & n.a. \\
\hline United Kingdom & n.a. & 433.43 & $\begin{array}{r}\text { n.a. } \\
\text { in } m \text { Euro }\end{array}$ \\
\hline
\end{tabular}

The values of countries reported both types of data are in most cases very similar. This means that information collected from national banks was almost completely used for the information exchange. However, there are also some cases for which there are huge differences as for Denmark in 2006. This shows that the exchange system and the data exchange and the reporting are still at the beginning. Improvements in the standardization have already been made and will lead to more coherent figures in coming years.

\section{b. Countries levying a withholding tax}

Table (4) displays available information, for the countries levying a withholding tax, about the amount of revenue shared with the Member States. The major part of revenue from the withholding tax in the second half of 2005, 2006 and 2007 was raised in Switzerland and Luxembourg. For both those periods, Switzerland accounted for more than $46 \%$ of the total amounts reported as regards withholding tax shared; Luxembourg's share was 23\%. Austria and Belgium accounted for $8.3 \%$ and 3.9\%, respectively, while Jersey and the Isle of Man contributed $6.2 \%$ and $4.2 \%$. All other countries have very low shares or have not yet reported the revenue shared in 2007. This shows that the largest payments that fall under the scope of the directive are made in Switzerland and Luxembourg. They account for almost $70 \%$ of all 
withholding tax revenue. Note that this figure is only based on the available data. Some countries did not report payments for some years.

\begin{tabular}{|c|c|c|c|}
\hline EU Member States & 2005 (2nd half) & 2006 & 2007 \\
\hline Austria & 9.48 & 44.32 & 59.53 \\
\hline Belgium & 7.51 & 19.61 & 25.92 \\
\hline Luxembourg & 35.90 & 124.59 & 153.00 \\
\hline \multicolumn{4}{|l|}{ Third Countries } \\
\hline Andorra & 3.50 & 12.77 & 16.34 \\
\hline Liechtenstein & 1.94 & 7.08 & 9.06 \\
\hline Monaco & 3.75 & 11.70 & n.a. \\
\hline San Marino & 1.13 & 7.47 & 10.75 \\
\hline Switzerland & 77.23 & 255.92 & 298.23 \\
\hline \multicolumn{4}{|c|}{ Dependent and Associated Territories } \\
\hline British Virgin Islands & 0.00 & n.a. & n.a. \\
\hline Turks and Caicos & 0.01 & 0.02 & n.a. \\
\hline Guernsey & 4.93 & 16.83 & n.a. \\
\hline Jersey & 13.26 & 32.15 & 38.34 \\
\hline Isle of Man & 13.26 & 20.35 & 23.39 \\
\hline Netherlands Antilles & n.a. & 0.05 & n.a. \\
\hline
\end{tabular}

Figure (6) shows the distribution of revenue from the withholding tax levied for the second half of 2005, 2006 and 2007. The graph only takes into account countries which received more than $10 \mathrm{~m}$ Euro in all years together. Unsurprisingly, the largest countries in the EU received the largest shares. Germany received $192.7 \mathrm{~m}$ Euro in 2005 and 2006, Italy 112.9m Euro followed by France and the United Kingdom (94.9m Euro). A notable exception is Belgium which received more than $71.6 \mathrm{~m}$ Euro. This is due to the close ties between Belgium and Luxemburg. Hence, the revenue received from Luxembourg accounts for 74\% of the Belgian part of the revenue.

Figure 6: Withholding tax collection 


\section{Received Withholding Tax Revenue \\ 2005 - 2007 im m Euro}

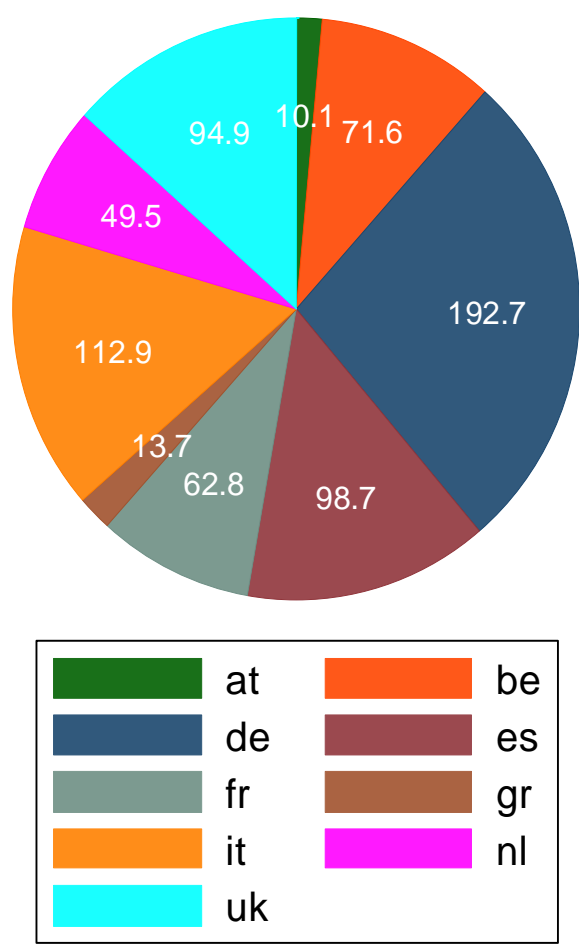

Source: European Commission

In conclusion, the data on information exchange from EU Member States and other jurisdictions show that reported interest payments increased significantly between the second semester of 2005 and 2006. In 2007 the development is more heterogeneous. While the information on payments and sales proceeds declined in Germany, Spain, Italy, and Switzerland, there was an increase in reported volumes in Ireland and Luxembourg. The data on withholding tax countries shows that Switzerland and Luxemburg are the main sources of withholding tax revenue while Germany, Italy and the UK receive the largest share of tax revenue. 


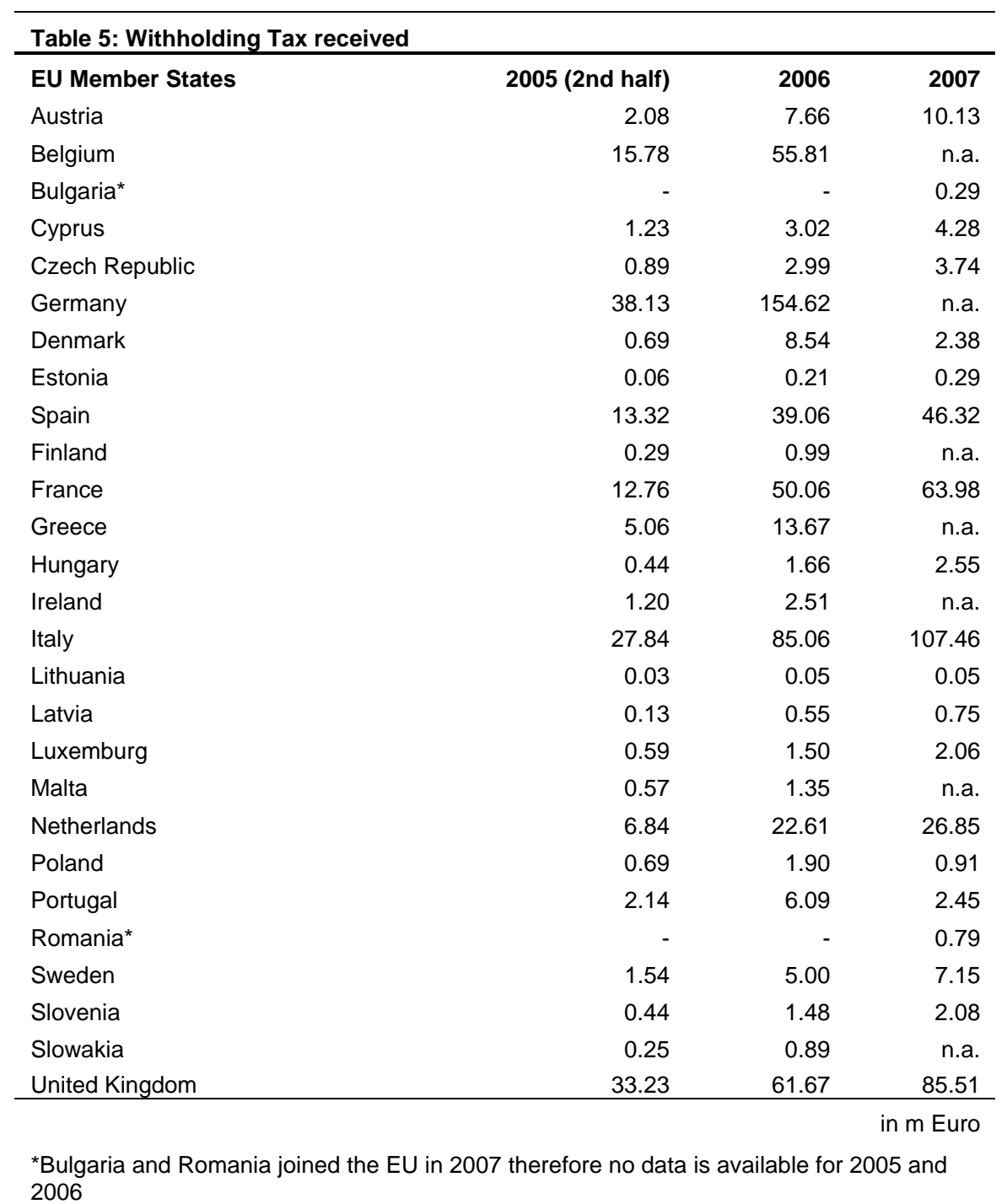

\subsection{Regression analysis}

This section seeks to estimate the possible effect of the introduction of the Directive on variables such as the level of interest received by households and on the share of interest in the total property income of households. Again, many caveats need to be made. First, the category of interest covered by the data is larger than that covered by the Directive and it is not known which percentage of the data actually concerns payments subject to the Directive. Secondly, changes in explanatory variables will influence different types of interest payments in different ways. For example, domestic inflation will have a different impact on domesticsource interest received than on foreign-source interest. Thirdly, data on interest received by individuals are only available for some EU countries and for 1995-2006. This means that the 
effects can only been seen for the last year or two. Fourthly, the effects of introduction of the Directive can only be captured by introducing a binary explanatory variable that takes the value one in the country-year pairs for which the Directive is in force. Because there are only one or two years for which this variable applies and because the geographical coverage of this variable does not vary, the variable may also simply act as a fixed effect for a group of countries during the last year of observations, picking up some unobserved effects that are common to EU Member States during this year.

Table (6) shows the results of the regressions for the effect of the Directive on interest received by households ${ }^{23}$. Regressions (1) to (3) show that the estimated effect of the introduction of the Directive is heavily dependent on the specification of the model. In particular, simply changing the proxy for the size of the country from the level of population to the level of GDP turns the effect of the Directive on the level of interest received by households from a positive and significant effect into a negative but non-significant one. It also turns out that the results are very sensitive to the inclusion of some controls. For example, omitting inflation in the regressions washes out the significance of the Directive variable in all regressions. This, combined with the wrong sign for some controls, places doubts on the statistical significance of the result that introducing the Directive decreased the share of interest in the property income of households.

Before explaining in detail the single regressions, it should be stated that the econometric analysis does not detect any major effect of the Directive on the dependent variables explained above. The share of interest received by households in the total interest received by individual and corporate recipients has decreased but this is mainly due to an increase in financial corporations' receipts. Equally, the share of interest in total property income received by households has declined in favour of dividends but this phenomenon

\footnotetext{
${ }^{23}$ Category "d4s14_s15 received" of the Sectoral Accounts
} 
started already in 2000. A regression analysis of the effect of the Directive on the level and the share of interest received by households shows some negative effects but those are not statistically robust. One reason could also be that some households decided to keep their portfolio structure despite the taxation because shifting to other investment vehicles could lead to an increase in the risk of the total portfolio.

Regressions (1) to (3) use the logarithm of the amount of interest received as dependent variable, while regressions (4) to (6) use the share of interest in the total property income received by households instead. The regressions include some control variables. The size of the country is supposed to have a positive effect on the amount of interest received by its households. This size is proxied by the logarithm of the population in regression (1) and (4). As an alternative, the logarithm of nominal GDP is used in the other four regressions. Next, inflation is expected to have an ambiguous effect on the amount of interest received by individuals. On the one hand, inflation increases the amount of any payment over time. On the other hand, interest payments are usually fixed and therefore investors may decide to shift to other investment vehicles. GDP growth is expected to have a negative effect on interest received because investors may prefer to choose investment vehicles which will include better returns such as stocks. Finally, the interest rate on deposits is used as a proxy for the interest rate. It is expected to have a positive effect on the level of interest received. Its effect on the share of interest is more ambiguous because the return on other investment types may follow the same pattern. Finally, all regressions include year dummies to control for unobserved year-specific effects that are common to all countries in the sample and all regressions except (3) and (6) include country dummies to control for unobserved countryspecific that are common for all years. 


\begin{tabular}{|c|c|c|c|c|c|c|}
\hline Variables & $\begin{array}{c}(1) \\
\text { Log interest }\end{array}$ & $\begin{array}{c}(2) \\
\text { Log interest }\end{array}$ & $\begin{array}{c}\text { (3) } \\
\text { Log interest }\end{array}$ & $\begin{array}{c}(4) \\
\text { Share interest }\end{array}$ & $\begin{array}{c}(5) \\
\text { Share interest }\end{array}$ & $\begin{array}{c}(6) \\
\text { Share interest }\end{array}$ \\
\hline Directive & $.347^{\star *}$ & -.160 & -.095 & $-.253^{\star \star}$ & $-.220^{\star *}$ & -.113 \\
\hline Log population & $\begin{array}{c}(2.67) \\
-13.459^{\star *} \\
(5.96)\end{array}$ & (.99) & $(.45)$ & $\begin{array}{l}(3.98) \\
1.104 \\
(1.10)\end{array}$ & (3.96) & (1.33) \\
\hline Inflation & $\begin{array}{l}-.005 \\
(0.85)\end{array}$ & $\begin{array}{l}-.009 \\
(1.52)\end{array}$ & $\begin{array}{l}-.015 \\
(1.82)\end{array}$ & $\begin{array}{l}-.003 \\
(1.59)\end{array}$ & $\begin{array}{l}-.002 \\
(1.18)\end{array}$ & $\begin{array}{l}-.003 \\
(0.84)\end{array}$ \\
\hline Deposit interest rate & $\begin{array}{l}.046^{* *} \\
(4.97)\end{array}$ & $\begin{array}{l}.048^{* *} \\
(5.60)\end{array}$ & $\begin{array}{l}.040^{* *} \\
(4.19)\end{array}$ & $\begin{array}{l}-.002 \\
(1.29)\end{array}$ & $\begin{array}{l}-.002 \\
(1.07)\end{array}$ & $\begin{array}{l}.008^{\star *} \\
(2.61)\end{array}$ \\
\hline Real GDP growth & $\begin{array}{l}-.023 \\
(0.85)\end{array}$ & $\begin{array}{l}-.030 \\
(1.43)\end{array}$ & $\begin{array}{l}-.020 \\
(0.84)\end{array}$ & $\begin{array}{l}-.014^{*} \\
(2.21)\end{array}$ & $\begin{array}{l}-.015^{\star} \\
(2.30)\end{array}$ & $\begin{array}{l}-.014 \\
(1.68)\end{array}$ \\
\hline Log nominal GDP & & $\begin{array}{l}2.019 * * \\
(7.37)\end{array}$ & $\begin{array}{l}1.323^{\star \star} \\
(37.25)\end{array}$ & & $\begin{array}{l}-.033 \\
(0.30)\end{array}$ & $\begin{array}{l}-.003 \\
(0.23)\end{array}$ \\
\hline Constant & $\begin{array}{l}194.249^{* *} \\
(6.07)\end{array}$ & $\begin{array}{c}-18.804^{\star *} \\
(4.62)\end{array}$ & $\begin{array}{c}-8.025^{\star *} \\
(15.33)\end{array}$ & $\begin{array}{l}-19.689 \\
(1.08)\end{array}$ & $\begin{array}{l}.920 \\
(0.94)\end{array}$ & $\begin{array}{l}.550^{\star} \\
(2.61)\end{array}$ \\
\hline Time dummies & Y & $\mathrm{Y}$ & Y & $\mathrm{Y}$ & Y & Y \\
\hline Country dummies & Y & Y & N & Y & Y & $\mathrm{N}$ \\
\hline Observations & 188 & 188 & 188 & 177 & 177 & 177 \\
\hline R-squared & 0.99 & 0.99 & 0.95 & 0.90 & 0.89 & 0.20 \\
\hline
\end{tabular}

In conclusion, regression analysis does not show a statistically significant and robust effect of the Savings Taxation Directive on the share of interest in the total property income received by households.

\section{Conclusion}

The entry into force of the Savings Taxation Directive in July 2005 constitutes a prime example of tax co-ordination at the European level. By introducing a system to ensure taxation of foreign interest income of domestic households in accordance with the same rules applicable to domestic interest income, EU Member States have made steps towards residence-based taxation and a reduction of tax evasion.

This paper provides an analysis of the functioning of the Savings Taxation Directive and analyses the evolution of proceeds from investments covered by the Directive. Despite poor data availability, the analysis suggests that the Directive had no significant effects on the development of the investment vehicles that fall under its scope. However, the current Directive suffers from several loopholes, which could explain this insignificant effect. 


\section{References}

Bacchetta, P. and M. P. Espinosa. (1995). Information Sharing and Tax Competition Among Governments. Journal of International Economics 39, 103-121.

Bacchetta, P. and M. P. Espinosa. (2000). Exchange-of-Information Clauses in International Tax Treaties. International Tax and Public Finance 7, 275-293.

Brennan, G. and Buchanan, J. (1980). The Power to Tax: Analytical Foundations of a Fiscal Constitution. Cambridge University Press.

Edwards, J. and Keen, M. (1996). Tax competition and Leviathan. European Economic Review, 40: 113-134.

Eggert, W. and M. Kolmar. (2002). Residence-Based Capital Taxation in a Small Open Economy: Why Information is Voluntarily Exchanged and Why it is Not. International Tax and Public Finance 9: 465-482.

Eggert, W. and M. Kolmar. (2004). The Taxation of Financial Capital Under Asymmetric Information and the Tax Competition Paradox. Scandinavian Journal of Economics 106: 83105.

Fuest, C., Huber, B. and J. Mintz (2005). Capital Mobility and Tax Competition: A Survey. Foundations and Trends in Microeconomics, Vol. 1(1): 1-62.

Gläser, L. (2007). Taxation of Cross-Border Savings: Options for Reviewing the European Approach. Intertax, 35(2): 726-734.

Gläser, L. and M. Halla (2008). Die EU-Zinsenrichtlinie: Ein Schuss in den Ofen? Perspektiven der Wirtschaftspolitik 9(1): 83-101.

Huizinga, H. and S. B. Nielsen. (2003). Withholding Taxes or Information Exchange: The Taxation of International Interest Flows. Journal of Public Economics 87: 39-72.

Huizinga, H. and G. Nicodème (2004). Are International Deposits Tax-Driven. Journal of Public Economics 88(6): 1093-1118.

Johannesen, N. (2009). Tax Evasion and Foreign Bank Deposits - Evidence from a natural experiment. University of Copenhagen. Mimeo.

Ligthart, J. and J. Voget (2008). The Determinants of Tax Information Sharing. Working Paper.

Jiménez, A.M. (2006). Loopholes in the EU Savings Directive. IBFD Bulletin, December: 480-494.

Keen, M. and J. E. Ligthart. (2006a). Information Sharing and International Taxation: A Primer. International Tax and Public Finance, 13(1): 81-110.

Keen, M. and J. E. Ligthart (2006b). Incentives and Information Exchange in International Taxation. International Tax and Public Finance, 13(2): 163-180. 
Keen, M. and J. E. Ligthart. (2007). Revenue Sharing and Information Exchange under Nondiscriminatory Taxation. Scandinavian Journal of Economics, 109(3): 487-504.

Klautke, T. and A. Weichenrieder (2008). Interest Income Tax Evasion, the EU Savings Directive, and Capital Market Effects. CESifo Working Paper, 2300.

Nicodème, G. (2007). Corporate tax competition and coordination in the European Union: what do we know? Where do we stand?, International Taxation Handbook, C. Read and G.N. Gregoriou editors, Elsevier, London, chapter 8: 171-208. 


\section{Appendix. Data sources}

\begin{tabular}{|c|c|c|}
\hline Data & Description & Source \\
\hline External loans and debt & $\begin{array}{l}\text { Bilateral external loans and debts of the banking sector in } 40 \text { BIS } \\
\text { members }\end{array}$ & BIS (restricted basis) \\
\hline Inbound and outbound interest and dividends & $\begin{array}{l}\text { For the EU-27, the amount of inbound and outbound interest and } \\
\text { dividend payments for individuals and corporations }\end{array}$ & $\begin{array}{l}\text { Eurostat Sectoral Account } \\
\text { Statistics }\end{array}$ \\
\hline $\begin{array}{l}\text { Amount of withholding tax, split by country of residence of } \\
\text { the beneficial owners }\end{array}$ & $\begin{array}{l}\text { For all Member States, Dependent and Associated Territories and } \\
\text { Third Countries having opted for the withholding tax mechanism, } \\
\text { total amount of tax revenue shared from the withholding tax, split } \\
\text { by MS of residence of the beneficial owners }\end{array}$ & Member States \\
\hline $\begin{array}{l}\text { Amount of withholding tax levied under article } 11(5) \text { of the } \\
\text { Directive, split by country or Territory of establishment of } \\
\text { residual entities }\end{array}$ & $\begin{array}{l}\text { This item concerns Austria, Belgium and Luxemburg as well as } \\
\text { the following Dependent and Associated Territories: Guernsey, } \\
\text { Jersey, Isle of Man, Turks and Caicos, British Virgin Islands and } \\
\text { the Netherlands Antilles. }\end{array}$ & Member States \\
\hline $\begin{array}{l}\text { Amount of interest payments and sales proceeds subject to } \\
\text { exchange of information / voluntary disclosure, split by } \\
\text { country of residence of the beneficial owners including } \\
\text { residual entities }\end{array}$ & $\begin{array}{l}\text { For all Member States, Dependent and Associated Territories and } \\
\text { Third Countries, amount of interest payments and sales proceeds, } \\
\text { split by country of residence of the beneficial owner and } \\
\text { establishment of the residual entities }\end{array}$ & Member States \\
\hline $\begin{array}{l}\text { Amount of interest payments subject to exchange of } \\
\text { information / voluntary disclosure under Art. 9, split by } \\
\text { country of residence of the beneficial owner }\end{array}$ & $\begin{array}{l}\text { For all Member States, Dependent and Associated Territories and } \\
\text { Third Countries, amount of interest payments (excluding sales } \\
\text { proceeds) split by country of residence of the beneficial owner - } \\
\text { Art. } 9\end{array}$ & Member States \\
\hline $\begin{array}{l}\text { Amount of sale proceeds subject to exchange of information } \\
\text { / voluntary disclosure under Art. } 9 \text {, split by country of } \\
\text { residence of the beneficial owners }\end{array}$ & $\begin{array}{l}\text { For all Member States, Dependent and Associated Territories and } \\
\text { Third Countries, amount of sales proceeds (excluding interest } \\
\text { payments), split by country of residence of the beneficial owner - } \\
\text { Art. } 9\end{array}$ & Member States \\
\hline $\begin{array}{l}\text { Amount of interest payments subject to exchange of } \\
\text { information / voluntary disclosure, split by country of } \\
\text { establishment of residual entities - Art. } 4.2\end{array}$ & $\begin{array}{l}\text { For all Member States, Dependent and Associated Territories and } \\
\text { Third Countries, amount of interest payments (excluding sales } \\
\text { proceeds), split by country of establishment of residual entities - } \\
\text { Art. } 4.2\end{array}$ & Member States \\
\hline $\begin{array}{l}\text { Amount of sales proceeds subject to exchange of } \\
\text { information / voluntary disclosure under Art. 4.2, split by } \\
\text { country of establishment of residual entities }\end{array}$ & $\begin{array}{l}\text { For all Member States, Dependent and Associated Territories and } \\
\text { Third Countries, amount of sales proceeds (excluding interest } \\
\text { payments), split by country of establishment of residual entities - } \\
\text { Art. } 4.2\end{array}$ & Member States \\
\hline $\begin{array}{l}\text { Amount of interest or sales proceeds subject to exchange of } \\
\text { information / voluntary disclosure, split by the categories of } \\
\text { Art. } 8.2 \text { of Directive 2003/48/EC }\end{array}$ & $\begin{array}{l}\text { For MS exchanging information, amount of interest payments or } \\
\text { sales proceeds subject to exchange of information split by the } \\
\text { categories of art. } 8.2 \text { of Directive 2003/48/EC }\end{array}$ & Member States \\
\hline
\end{tabular}




\begin{tabular}{|l|l|l|}
\hline Data & Description & Source \\
\hline Deposit rate & Deposit interest rates for EU and BIS countries & $\begin{array}{l}\text { IMF International } \\
\text { Financial Statistics }\end{array}$ \\
\hline Nominal GDP & Nominal GDP & Ameco \\
\hline Real GDP growth & Real GDP growth & Eurostat \\
\hline Population & Number of inhabitants & $\begin{array}{l}\text { Eurostat, CIA Factbook, } \\
\text { NationMaster.com }\end{array}$ \\
\hline Inflation & Deflator of GDP & $\begin{array}{l}\text { Computed from nominal } \\
\text { and real GDP growth }\end{array}$ \\
\hline
\end{tabular}




\section{CESifo Working Paper Series}

for full list see www.cesifo-group.org/wp

(address: Poschingerstr. 5, 81679 Munich, Germany, office@cesifo.de)

2613 Michael Melvin, Christian Saborowski, Michael Sager and Mark P. Taylor, Bank of England Interest Rate Announcements and the Foreign Exchange Market, April 2009

2614 Marie-Louise Leroux, Pierre Pestieau and Gregory Ponthiere, Should we Subsidize Longevity?, April 2009

2615 Ronald MacDonald, Lukas Menkhoff and Rafael R. Rebitzky, Exchange Rate Forecasters' Performance: Evidence of Skill?, April 2009

2616 Frederick van der Ploeg and Steven Poelhekke, The Volatility Curse: Revisiting the Paradox of Plenty, April 2009

2617 Axel Dreher, Peter Nunnenkamp, Hannes Öhler and Johannes Weisser, Acting Autonomously or Mimicking the State and Peers? A Panel Tobit Analysis of Financial Dependence and Aid Allocation by Swiss NGOs, April 2009

2618 Guglielmo Maria Caporale, Roman Matousek and Chris Stewart, Rating Assignments: Lessons from International Banks, April 2009

2619 Paul Belleflamme and Martin Peitz, Asymmetric Information and Overinvestment in Quality, April 2009

2620 Thomas Dohmen, Armin Falk, David Huffman and Uwe Sunde, Are Risk Aversion and Impatience Related to Cognitive Ability?, April 2009

2621 Yin-Wong Cheung and Xingwang Qian, The Empirics of China's Outward Direct Investment, April 2009

2622 Frédérique Bec and Christian Gollier, Assets Returns Volatility and Investment Horizon: The French Case, April 2009

2623 Ronnie Schöb and Marcel Thum, Asymmetric Information Renders Minimum Wages Less Harmful, April 2009

2624 Martin Ruf and Alfons J. Weichenrieder, The Taxation of Passive Foreign Investment Lessons from German Experience, April 2009

2625 Yao Li, Borders and Distance in Knowledge Spillovers: Dying over Time or Dying with Age? - Evidence from Patent Citations, April 2009

2626 Jim Malley and Ulrich Woitek, Technology Shocks and Aggregate Fluctuations in an Estimated Hybrid RBC Model, April 2009

2627 Jin Cao and Gerhard Illing, Endogenous Systemic Liquidity Risk, April 2009 
2628 Thiess Buettner and Bjoern Kauder, Revenue Forecasting Practices: Differences across Countries and Consequences for Forecasting Performance, April 2009

2629 Håkan Selin, The Rise in Female Employment and the Role of Tax Incentives - An Empirical Analysis of the Swedish Individual Tax Reform of 1971, April 2009

2630 Nick Johnstone and Ivan Hascic, Environmental Policy Design and the Fragmentation of International Markets for Innovation, April 2009

2631 Spiros Bougheas, Richard Kneller and Raymond Riezman, Optimal Education Policies and Comparative Advantage, April 2009

2632 Jay Pil Choi and Heiko Gerlach, Multi-Market Collusion with Demand Linkages and Antitrust Enforcement, April 2009

2633 Thor O. Thoresen, Income Mobility of Owners of Small Businesses when Boundaries between Occupations are Vague, April 2009

2634 Guido Schwerdt and Amelie C. Wuppermann, Is Traditional Teaching really all that Bad? A Within-Student Between-Subject Approach, April 2009

2635 Kurt R. Brekke, Luigi Siciliani and Odd Rune Straume, Hospital Competition and Quality with Regulated Prices, April 2009

2636 Peter Diamond, Taxes and Pensions, April 2009

2637 Shoshana Grossbard, How "Chicagoan” are Gary Becker's Economic Models of Marriage?, May 2009

2638 Roland Strausz, Regulatory Risk under Optimal Incentive Regulation, May 2009

2639 Holger Zemanek, Ansgar Belke and Gunther Schnabl, Current Account Imbalances and Structural Adjustment in the Euro Area: How to Rebalance Competitiveness, May 2009

2640 Harald Hau and Marcel Thum, Subprime Crisis and Board (In-)Competence: Private vs. Public Banks in Germany, May 2009

2641 Martin Halla, Mario Lackner and Friedrich G. Schneider, An Empirical Analysis of the Dynamics of the Welfare State: The Case of Benefit Morale, May 2009

2642 Balázs Égert, Infrastructure Investment in Network Industries: The Role of Incentive Regulation and Regulatory Independence, May 2009

2643 Christian Gollier, Expected Net Present Value, Expected Net Future Value, and the Ramsey Rule, May 2009

2644 Sören Blomquist and Håkan Selin, Hourly Wage Rate and Taxable Labor Income Responsiveness to Changes in Marginal Tax Rates, May 2009 
2645 Dominique Demougin, Oliver Fabel and Christian Thomann, Implicit vs. Explicit Incentives: Theory and a Case Study, May 2009

2646 Francesco C. Billari and Vincenzo Galasso, What Explains Fertility? Evidence from Italian Pension Reforms, May 2009

2647 Kjell Arne Brekke, Karen Evelyn Hauge, Jo Thori Lind and Karine Nyborg, Playing with the Good Guys - A Public Good Game with Endogenous Group Formation, May 2009

2648 Guglielmo Maria Caporale and Luis A. Gil-Alana, Multi-Factor Gegenbauer Processes and European Inflation Rates, May 2009

2649 Henning Bohn, A Static Model for Voting on Social Security, May 2009

2650 Markus Haavio and Kaisa Kotakorpi, The Political Economy of Sin Taxes, May 2009

2651 Augusto de la Torre, María Soledad Martínez Pería and Sergio L. Schmukler, Drivers and Obstacles to Banking SMEs: The Role of Competition and the Institutional Framework, May 2009

2652 Tobias Lindhe and Jan Södersten, Dividend Taxation, Share Repurchases and the Equity Trap, May 2009

2653 Assaf Razin and Edith Sand, Migration-Regime Liberalization and Social Security: Political-Economy Effect, May 2009

2654 Yin-Wong Cheung and Hiro Ito, A Cross-Country Empirical Analysis of International Reserves, May 2009

2655 Bart Cockx and Bruno Van der Linden, Flexicurity in Belgium. A Proposal Based on Economic Principles, May 2009

2656 Michael Melvin, Lukas Menkhoff and Maik Schmeling, Exchange Rate Management in Emerging Markets: Intervention via an Electronic Limit Order Book, May 2009

2657 Susanne Neckermann, Reto Cueni and Bruno S. Frey, What is an Award Worth? An Econometric Assessment of the Impact of Awards on Employee Performance, May 2009

2658 Steven Brakman, Harry Garretsen and Charles van Marrewijk, Economic Geography within and between European Nations: The Role of Market Potential and Density across Space and Time, May 2009

2659 Giovanni Facchini and Cecilia Testa, Reforming Legislatures: Is one House better than two?, May 2009

2660 Carsten Kowalczyk and Raymond Riezman, Trade Agreements, May 2009 
2661 Oliver Falck, Stephan Heblich and Elke Luedemann, Identity and Entrepreneurship, May 2009

2662 Christian Lessmann and Gunther Markwardt, One Size Fits All? Decentralization, Corruption, and the Monitoring of Bureaucrats, May 2009

2663 Felix Bierbrauer, On the Legitimacy of Coercion for the Financing of Public Goods, May 2009

2664 Alessandro Cigno, Agency in Family Policy: A Survey, May 2009

2665 Claudia M. Buch and Christian Pierdzioch, Low Skill but High Volatility?, May 2009

2666 Hendrik Jürges, Kerstin Schneider, Martin Senkbeil and Claus H. Carstensen, Assessment Drives Learning: The Effect of Central Exit Exams on Curricular Knowledge and Mathematical Literacy, June 2009

2667 Eric A. Hanushek and Ludger Woessmann, Schooling, Cognitive Skills, and the Latin American Growth Puzzle, June 2009

2668 Ourania Karakosta, Christos Kotsogiannis and Miguel-Angel Lopez-Garcia, Does Indirect Tax Harmonization Deliver Pareto Improvements in the Presence of Global Public Goods?, June 2009

2669 Aleksandra Riedl and Silvia Rocha-Akis, Testing the Tax Competition Theory: How Elastic are National Tax Bases in OECD Countries?, June 2009

2670 Dominique Demougin and Carsten Helm, Incentive Contracts and Efficient Unemployment Benefits, June 2009

2671 Guglielmo Maria Caporale and Luis A. Gil-Alana, Long Memory in US Real Output per Capita, June 2009

2672 Jim Malley and Ulrich Woitek, Productivity Shocks and Aggregate Cycles in an Estimated Endogenous Growth Model, June 2009

2673 Vivek Ghosal, Business Strategy and Firm Reorganization under Changing Market Conditions, June 2009

2674 Francesco Menoncin and Paolo M. Panteghini, Retrospective Capital Gains Taxation in the Real World, June 2009

2675 Thomas Hemmelgarn and Gaëtan Nicodème, Tax Co-ordination in Europe: Assessing the First Years of the EU-Savings Taxation Directive, June 2009 